\title{
2
}

\section{Environmental Change in the Aru Islands}

\author{
Geoffrey Hope ${ }^{1}$ and Ken Aplin² \\ 1. Archaeology and Natural History, Research School of Pacific and Asian Studies, \\ The Australian National University, Canberra, ACT, Australia \\ 2. Sustainable Ecosystems, CSIRO, GPO Box 284, Canberra, ACT 2601, Australia
}

\section{Introduction}

The Aru archipelago has attracted scientific interest over the past two centuries because of its position as a 'lifeboat' of the former Torresian plain of the continent of Sahul. Yet despite a lengthy visit by Wallace (1857, 1869; see Chapter 1, this volume), and subsequent studies of birds and other biota (e.g. van Balgooy and Nooteboom 1995; Monk et al. 1997; Flannery 1995), and geomorphology (Verstappen 1959), virtually no comprehensive environmental studies have been published with the exception of Nooteboom (1996). Although remoteness has been blamed for this state of affairs, the islands have experienced more than two centuries of reasonable communications and significant business activity based on pearling, bird of paradise feathers, and most recently timber extraction and commercial fishing. The islands have failed to attract comprehensive scientific work despite being known to western science, perhaps because New Guinea became accessible. For example, the large British Ornithological Union expedition called in at Dobo in 1910 as the last western outpost before tackling the New Guinean coast (Wollaston 1912), but made no studies on Aru.

This chapter reviews what is known of the Aru natural environments, and provides a background to the archaeology by deducing the past environments and palaeoclimates from regional studies such as marine palynology (van der Kaars et al. 1997), reconstruction of past shorelines from bathymetry and isostatic modelling (e.g. Voris 2000; Yokoyama et al. 2001a), and limited local data. The major discovery by the present research team, of faunal change in the past that reflects climate change, is dealt with in detail in Chapters 7 and 9. These findings are summarized here and set in a regional context. 


\section{The Aru Region}

\section{Topography and regional setting}

The Aru Islands lie on the western edge of the shallow seas of Torres Strait, around $7^{\circ} \mathrm{S}$ and $134^{\circ} \mathrm{E}$ (see Chapter 1, Fig. 1.1). The group is quite discrete, for their nearest neighbours are the Kei Islands of the Banda outer arc, $130 \mathrm{~km}$ to the west, and New Guinea $110 \mathrm{~km}$ to the north. To the south, the shelf is deeper $(60-80 \mathrm{~m})$ until Croker Island in northern Australia is reached $(510 \mathrm{~km})$. The archipelago consists of about 80 islands greater than $40 \mathrm{ha}$, and a further 80 that are smaller, totalling ca. $8225 \mathrm{~km}^{2}$ (van Balgooy 1996). The islands lie very close to one another. The seven largest, with a combined land area of $7050 \mathrm{~km}^{2}$, are separated only by narrow channels and are effectively one land mass. The highest point on the islands is $241 \mathrm{~m}$ altitude on Kobroor, but the other large islands generally reach only $50-100 \mathrm{~m}$ altitude, becoming lower to the south. The sea around the islands is shallow, generally less than $20 \mathrm{~m}$ in depth, and a slight submarine ridge connects them eastwards to Yos Sudarso (Prinz Hendrik) Island in New Guinea.

A very significant aspect of the Aru islands is that they lie within a region of macro-tides that extends from the northwest Australian coast. Open water spring tides have a range of $1.5 \mathrm{~m}$ (British Admiralty 1998) but can vary in closed estuaries to considerably more depending on the lunar cycle and prevailing winds, resulting in a very variable shoreline environment.

\section{Geology and geomorphology}

Torres Strait and the southern plains of West Papua and Papua New Guinea are a submerged extension of the Australian continental plate, which has enjoyed relative stability since the Proterozoic. Sediments in the Northern Territory are around 500-700 million years in age but include gently folded sandstones. Granites, rhyodacites, shales, and quartzites are also common and occur in southern Papua. Some basins occur in the east and reflect Cretaceous or earlier sea ways. The shelf is mantled by late Neogene and Quaternary sediments a few hundred metres in thickness. The Aru Islands are uplifted Pliocene and Quaternary marly limestone, siltstone and sandstone sediments, that are domed up as a high point on the shelf (Gregory et al. 1924; Verstappen 1959). They are mostly horizontal or gently dipping beds of similar lithology to the modern shelf sediments forming in shallow seas. Corals are rare in the limestones and this matches the situation in shallow areas around the group, where coral reefs are quite restricted but shell beds and calcareous sandy muds are common (Verstappen 1959). Some bedding horizons onshore are marked by lines of scallop and oyster shells. The bedding is consistent with Verstappen's interpretation of a large geanticline: a gently arched structure over $100 \mathrm{~km}$ across. Older cratonic bedrock may not be far down, since coarse quartz, mica and feldspar have been seen on the southeast part of Pulau Trangan (Verstappen 1959).

There is a low drainage density due to the absorption of surface water by the marls, although seasonal stream ways are common and some flowing water occurs from springs. Dry or internally draining valleys are found in the raised karst, but on lowland plains clays and silts mantle some hills and valleys, allowing surface flow and shallow streamlines in heavy rain. Lakes are rare except for a few small karst hollows on Kobroor and Trangan Islands. Van Balgooy (1996) also notes the occurrence of permanent and seasonal ponds and swamps on Trangan Island. Springs occur along the cliffed coast and interior gorges.

The Aru Islands are famous for the sungai, a series of about eight major channels that traverse the islands or penetrate deeply into them (see Chapter 1, Fig. 1.2). These waterways are like rivers, but are flooded by the sea. The channels are 100-300m wide, and incised $20-100 \mathrm{~m}$ deep in gorges through the hills. They are usually $10-20 \mathrm{~m}$ deep, but in places are scoured out to well below the level of the sea floor. The three largest - Sungai Manumbai, S. Workai, and S. Maikoor — separate 
Wokam, Kobroor, Koba and Trangan Islands, and are up to 50km in length with side channels and connections. The high tidal range causes rapid flow in both directions twice a day, providing an obvious mechanism for maintaining the channels. In places the limestone cliffs are notched at high water level, indicating that solution is active. The width and depth of the channels varies greatly. At low tide the main channels remain water filled but side channels drain, exposing kilometres of mangrove muds or rocky solution surfaces with sharp edges. Extremely high tides sometimes leave a band of open scald land behind the dense mangrove forest in the zone of daily flooding.

Verstappen (1959) discusses the various theories for formation of these channels. He concludes that they are the result of solution along joint cracks that are concentrated in NNW-SSE and NNE-SSW directions, symmetrical to the north-south axis of the group. The jointing may be the result of relatively recent or even continuing shear planes on the geanticlinal upwarp. Once the joints had enlarged and captured local drainage they cut down by flow and solution to the level of the shelf. On being flooded by rising sea level they were scoured out and cut by active tidal flows. During low sea levels they may have been a series of freshwater lakes and streamways, fed by active springs.

Away from the steep banks of the sungai the islands have gentle slopes, although steep scarps and low ridges occur. Soils are shallow on the limestone, and ridges of rock are common under the forest. Karstic landforms are not very common, as the limestone is porous and solution general. However, numerous dolines and lines of collapsed tunnel caves occur. These tunnel caves, mostly seen on Kobroor Island, are often located near the top of ridgelines, with thin roofs. They must represent a former underground drainage that is now abandoned due to general surface lowering and the development of deeper drainage.

The coastline is generally steep with low $(5-10 \mathrm{~m})$ cliffed or steep sections, which on the west coast often lie behind calcareous sand beaches or mud flats. These cliffs are the result of marine erosion during the earliest period of sea level rise, following which progradation has led to a generally low energy coastline, invaded in many areas by mangroves or protected by offshore reefs and mud flats.

\section{Climate}

The islands lie in the extreme east of the Indian ocean but are sheltered by the islands to the southwest around Timor and Nusa Tenggara. For most of the year surface water flows to the northwest under the influence of the southeast trade winds, and warm Torres Strait water derived from the Coral Sea inflow surrounds the islands. A warm current also flows below surface drift to the south and west to form the unusual Leeuwin current of the Western Australian coast. During the northwest monsoon, from November to March, large rainfall systems pass eastwards and surface currents in Torres Strait are reversed. At this time rainfall is heavy and there are widespread thunderstorms. Rainfall data is scanty for the archipelago; the rainfall maps of Monk et al. (1997) suggest that the rainfall is about $2000 \mathrm{~mm}$ per annum on the western coast of Trangan Island, rising east and north to possibly $3000 \mathrm{~mm}$ in the interior of Kobroor. Dobo has an annual rainfall of 2078mm (van Balgooy 1996), and probably lies in a slight rainshadow (Table 2.1).

Table 2.1 Dobo rainfall (from van Balgooy 1996)

\begin{tabular}{lcccccccccccc}
\hline MONTH & JAN & FEB & MAR & APR & MAY & JUN & JUL & AUG & SEPT & OCT & NOV & DEC \\
\hline $\mathrm{mm}$ & 272 & 229 & 200 & 153 & 154 & 116 & 63 & 78 & 115 & 164 & 243 & 234 \\
Rain days & 15.3 & 15.6 & 14.8 & 13.9 & 12.9 & 12.0 & 9.1 & 6.8 & 7.5 & 8.9 & 11.8 & 14.8 \\
\hline
\end{tabular}

Much of Aru is more southerly than the Kei Islands where rainfall is better studied. On Kei Kecil the rainfall is estimated to be only $1400 \mathrm{~mm}$ at the southern tip and hence it is possible that the rainfall of southern Aru has been overestimated. There is a marked gradient in seasonality, the 
southern part experiencing a pronounced dry season each year of about 4 months with monthly rainfall less than $100 \mathrm{~mm}$, while the northern half has a less pronounced winter minimum. In comparison to more southerly islands such as Tanimbar, Timor and Sumba, Aru has a moist climate with a relatively modest water deficit, comparable with southern New Guinea and the tip of Cape York, Australia. The islands lie generally north of the tropical cyclone zone but have experienced very occasional high winds. For example, a cyclone formed off northwest Aru in April 1920 and travelled between Aru and Kei (Monk et al. 1997). Temperatures are slightly cooler in May-August and the diurnal fluctuations greater, with an estimated mean of $28.5^{\circ} \mathrm{C}$. The islands are affected by El Niño fluctuations, and were in a state of pronounced drought when visited in the 1997-98 very severe ENSO event. However, local thunderstorms provided some relief and the forest was not greatly stressed.

\section{Vegetation}

The formational boundary between closed tropical forest and more open savannah woodlands and sclerophyll forest runs across the group. Despite active logging, the botany is still incompletely known and no quantitative surveys are available, but descriptions have been given by van Balgooy and Nooteboom (1995) and van Balgooy (1996). The latter predicts that over 2000 species of plants may be present. The natural vegetation of the northern islands (Wokam, Kobroor and Koba) consists of tall forest about $40-60 \mathrm{~m}$ in height, with emergents to $60 \mathrm{~m}$ such as dipterocarps, Pometia pinnata (Sapindaceae), Alstonia scholaris (Apocynaceae), and Syzygium (Myrtaceae) and Ficus species (Moraceae). Van Balgooy (1996) notes several species as important in the main canopy, namely Canarium spp., Flindersia amboinensis, Dillenia pteropoda, Instia bijuga (merbau), Maranthes corymbosa, and Podocarpus spp. Smaller trees include species of Elaeocarpus, Diospyros, Cryptocarya, Litsea, Myristica, Rauwolfia, Kibara, Gardenia, Fagraea, Antidesma, and Macaranga. Van Balgooy and Nooteboom (1995) suggest that the flora is remarkably rich, incorporating both west Malesian and AustraloPapuan taxa, and hence more diverse than that occurring in other Maluku islands. They also found very marked patchiness, with species common in one location but rare or lacking in another.

Although the forests are rich rainforest, they are relatively open in the understorey and canopy gaps are numerous. On limestone, dry forest floor conditions prevail, so that ferns and epiphytes are less common than in other rainforest areas. Walking is thus relatively easy and numerous small tracks run between clearings, making access from the sungai good for hunting. Secondary forest, with tell-tale regrowth trees such as Acalypha, Glochidion, and Macaranga, is quite widespread along major tracks and around sago palm areas.

The savannah on Trangan Island is an open woodland to about $15-20 \mathrm{~m}$ in height, dominated by a wide array of myrtaceous shrubs and trees. Examples are Melaleuca leucadendron, M. caja-putih, Lophostemon suaveolens, Asteromyrtus symphiocarpa, Xanthostemon brassii, and Syzygium species (spp.). Banksia dentata, Acacia mangium, Pandanus spp., and Timonius timon are also found but are not ubiquitous. The undergrowth includes numerous shrubs and hummock graminoids such as Lomandra banksii, and parasitic epiphytes and climbers are common, for example Hydnophytum, Myrmecodia, and Cladomyza stellata. Grasses, principally Eriachne squarrosa, E. triseta, Eragrostis lasioclada, and Digitaria fuscescens, form an open bunch cover. During the rainy season moistureloving sedges, restiads such as Leptocarpus spp., Xyris bancana and X. oligantha, and pitcher plants (Nepenthes spp.) do well, and a herb layer of Drosera, Leschenaultia filiformis, Centrolepis banksii, Wahlenbergia marginata and Mitrasacme pygmaea becomes common in waterlogged areas (van Balgooy 1996). During the dry season fires are very common but the savannah species are adapted to resprout and recover.

Van Balgooy (1996) found patches of rainforest along watercourses and in fire sheltered rises on Trangan Island. The gallery rainforests grow well due to the permanent flow of streams on Trangan, which has less limestone than the northern islands. Ficus, Syzygium, Alloxylon brachycarpum, 
and Dubouzetia galorei are common here, and sago palm (Metroxylon sagu) occurs naturally or is planted. He also records huge buttressed Melaleuca leucodendron trees within rain forest on Kobroor Island. However, these former patches of savannah in the rainforest are not regenerating and must represent old openings in the forest.

There are also areas of stunted forests or shrublands $5-10 \mathrm{~m}$ in height on areas of bare limestone pavement. This heath of poor soils or kerangas (in Malay) supports Ilex, Vavea, Glochidion, Acronychia and Diospyros shrubs, and the epacridaceous Dracaena angustifolia. In addition there are coastal forests of Barringtonia asiatica and Calophyllum inophyllum, with coconuts, Hibiscus tiliaceus, Terminalia catappa, and Casuarina equisetifolia. Shrubs include the boraginaceous Tournefortia argentea and Scaevola sericea. The other major coastal formation is widespread mangroves, such as Rhizophora apiculata, R. stylosa, Ceriops tagal, and Bruguiera cylindrica. Avicennia officinalis, Sonneratia caseolaris, Xylocarpus granatum and Camptostemon schultzii are also widespread. There is a high diversity of mangrove taxa, van Balgooy (1996) noting seventeen species, forming communities described by Gylstra (1996). Rearwards of mangroves are limited areas of swamp forest with sago palm and Barringtonia sp. above a ground layer of sedges and mangrove fern.

The savannah formation has strong relationships with southern Papua and northern Australia, especially Cape York. Curiously, Eucalyptus is absent (despite being on Timor and at similar latitudes in southern New Guinea) but the species of Melaleuca in Aru are widespread in northern Australia, where they occur as the dominants of a major open forest community of seasonally flooded plains. Asteromyrtus symphiocarpa and probably several other species are found in Aru and on Cape York, possibly representing a remnant of a savannah that once occupied the land now flooded by Torres Strait.

The change from savannah to closed rainforest on Trangan Island marks the modern position of a major biome boundary that occurs also in southern New Guinea around Merauke, Daru and Port Moresby, and on eastern Cape York. Relatively few deciduous tree species occur in the transitional rainforest, although substantial leaf fall does occur in many rainforest species during the dry season. The rainforest includes many taxa found only in New Guinea such as the dipterocarps Anisoptera thurifera and Hopea iriana but some (e.g. Celtis philippinensis, Diospyros sp.) extend to northern Australia or to the west. The coastal vegetation is far more cosmopolitan, with some strand species such as Scaevola sericea extending to the furthest edge of the Pacific.

\section{Fauna}

The contemporary vertebrate fauna of the Aru Islands is quite diverse and contains a high proportion of typically Australo-Papuan groups such as marsupials (e.g. wallabies, possums and a bandicoot), birds of paradise, and cassowaries. In contrast, the faunas of nearby oceanic Moluccan islands (e.g. the Kei Islands) are far less diverse, being particularly depauperate in both mammals and reptiles, and containing far fewer Australo-Papuan elements. This very clearly reflects the location of the Aru Islands on the continental shelf and its former landbridge connection with southern New Guinea.

All of the mammal, bird and reptile species found on the Aru Islands today are also present in southern New Guinea. However, the archaeological record contains evidence of a more diverse vertebrate fauna during late Pleistocene times. As discussed in more detail by Aplin and Pasveer (Chapter 3, this volume), the late Pleistocene mammalian fauna of the Aru Islands shows evidence of strong biogeographic continuity with the contemporary fauna of the Trans-Fly region of southern New Guinea. The Trans-Fly area was identified by Flannery (1995) as part of a broader zoogeographic province that he labelled the 'Austral Province'. This province also includes several extensive tracts of savannah woodland in southeast Papua New Guinea, most notably around Port Moresby and Popondetta. Today, the Aru Islands make up part of Flannery's 'Tumbunan Province', which otherwise includes the extensive tracts of rainforest on New Guinea and its major 
satellite islands.

As noted above, the boundary between closed tropical forest and more open savannah woodlands and sclerophyll forest runs across Trangan Island, in the south of the group. The fauna of the savannah habitats on Trangan has not been surveyed to any extent and it is possible that additional mammal species may persist there.

\section{Conservation}

The Aru Islands contain 66,487ha of nature conservation forest, 217,866ha of limited production forest, and 457,991ha of conservation forest (Hidayat 2000). Forest degradation is occurring on the islands, for example on Wokam and Maikor Islands. The main causes are the lack of control by forest administrators over the exploitation of forests by companies. One logging company is working in Aru - P.T. Budhi Nyata - on a concession of 98,000ha of forest. This company employed 312 workers in 1998, some of whom are locals, but the majority of workers come from outside the Aru Islands. Many species of trees are logged, including kayu Besi (Eusideroxylon zwageri), kayu Kenari (Canarium amboinense), kayu Gofasa (Vitex cofassus), kayu Merah (Eugenia rumphii), and kayu Bawang (Dysoxylum euphlebium). In addition, local people cut kayu Burung, kayu Dompet, kayu Nyato, and kayu Gofasa for house-building and furniture-making.

With changes to the Forestry law in 1967, communal rights (hak ulayat) to forest in the Outer Islands ceased to be recognized by the government, leading to some land conflicts in Aru between local people and logging concessionaires. In this conflict, the government usually takes the side of, and maintains relations with, the logging companies, since it receives benefits (stumpage fees, or replanting fees) from the owners of concessions (Hidayat 2000). In practice, about $15 \mathrm{~km}^{2}$ around villages can be utilized by local people for forest products for their daily needs, such as housing material, furniture, fishing tools, etc. New conservation laws, intended to protect the bird life and other protected species, have also been introduced, but Aru remains a centre for smuggling of parrots and bird of paradise (Monk et al. 1997).

\section{Change Since The Late Pleistocene}

\section{Torresian plain to islands}

Situated on the Australian continental plate, the Aru Islands have enjoyed a high degree of stability by comparison with the tectonically active plate boundary provinces to the north and west. Any uplift or downwarping has been slow and of low magnitude. The land mass has experienced continuing tropical weathering and gradual erosion for probably all of the Pleistocene. This has led to mature landforms with inverted topographies, in which the old stream ways (indicated by caves) are sometimes preserved in crestal positions. The most obvious environmental changes are associated with the changes in sea level caused by change in the global ice volume (Chappell et al. 1996; Yokoyama et al. 2001b). Because the surrounding shelf is between $40-60 \mathrm{~m}$ deep, the islands become low hills on a vast plain at times of lowered sea levels (Voris 2000).

Yokoyama et al. (2001a) illustrate the Torresian plain at five time periods. Their shorelines are reconstructed from a consideration of the global sea level change modified by hydro-isostatic effects. These reflect the sinking of the crust when loaded by water as sea level rises, and on such a huge shelf the effect is significant (Fig. 2.1). At the lowest sea level $(-115 \mathrm{~m})$, the Aru Islands lie $20 \mathrm{~km}$ from the western end of the shelf but are directly connected to New Guinea, although a large river draining the whole southern slopes of the mountain range of Papua, possibly flowed westward between the low hills and the mountains to the north. A broad shallow bay lay $70 \mathrm{~km}$ south. As the sea level rises, the shoreline of this bay creeps eastward although little change is evident at $16,000 \mathrm{BP}$, despite a rapid rise after $17,000 \mathrm{BP}$ to $-90 \mathrm{~m}$. By $12,000 \mathrm{BP}(-42 \mathrm{~m})$ the 

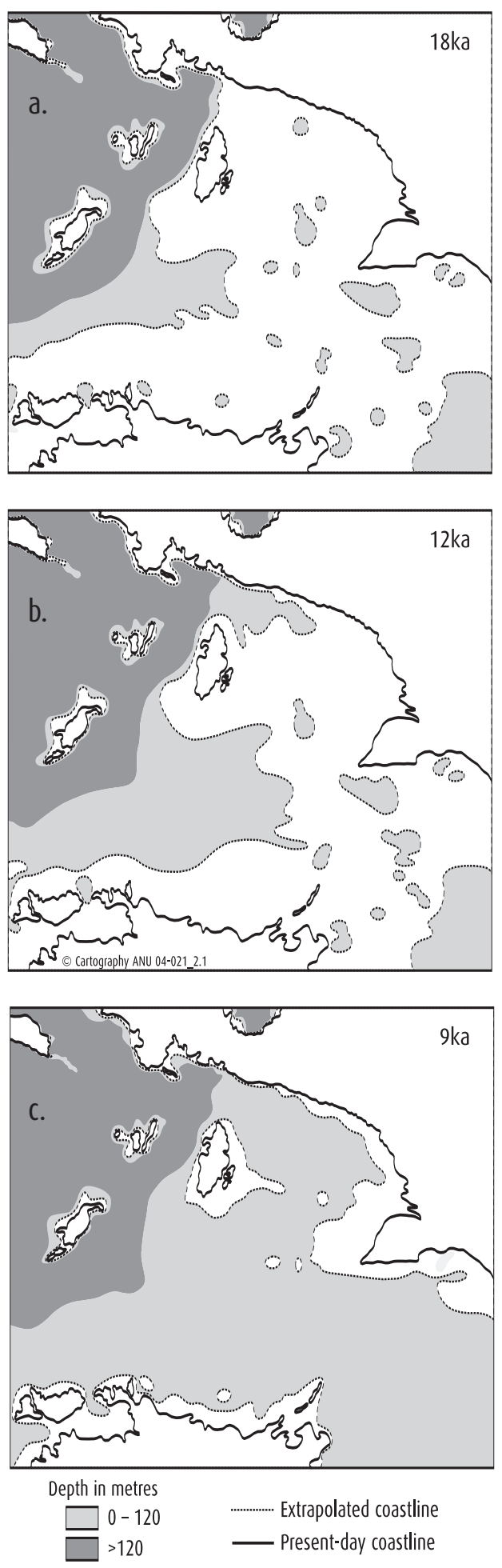

Figure 2.1 Palaeo-shoreline maps for the western Arafura shelf: LGM at 18,000 BP, 12,000 BP and 9000 BP. Bathymetric contours indicated by changes in shading at depths $0-120 \mathrm{~m}$ and $>120 \mathrm{~m}$. Adapted from data in Yokoyama et al. (2001a) embayment is expanding rapidly northward and southward, and the sea is flooding up the northern valley as well. Aru, however, is still the western end of a broad peninsula to Papua, and the connection south from there to Australia is intact. Within another 1500 years $(-25 \mathrm{~m})$ though, these connections are lost, and by 9000 years ago $(-16 \mathrm{~m})$ Aru is a single island about twice as large as present, with a western coast close to the present but a broad plain extending out on the east.

One aspect that is still unknown is how tidal regimes may have changed with changing land extent. Tidal range may have been less until a broad expanse of sea way had formed in the Holocene. Thus the sungai may have changed in character as the sea level rose and their modern flow regime became established. When sea levels were depressed they must have acted as freshwater streams with probable flows to the west. As they are deeper than the surrounding plain they may have also provided chains of permanent freshwater lakes fed by springs in the limestone.

The modern shoreline is reached before $6000 \mathrm{BP}$, at which time the sungai separate the modern islands from each other. Global sea level may have fallen by $1-2 \mathrm{~m}$ since then, but this has probably been offset by

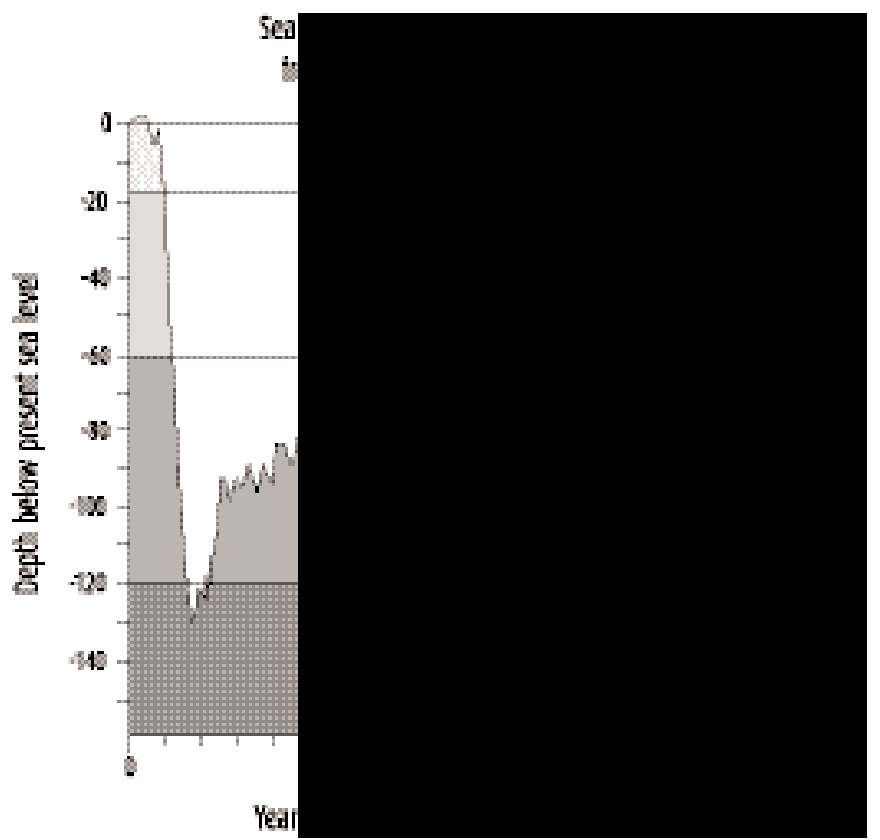

Figure 2.2 Sea level fluctuations of the last 150,000 years, based on the oxygen isotope record of Martinson et al. (1987). Connections between Aru and New Guinea are severed at ca. $-18 \mathrm{~m}$ 
sinking of the outer shelf. Aru may be subsiding slightly, but early Holocene coastal features such as cliffed coastlines and beach ridges are preserved up to $1 \mathrm{~km}$ inland, suggesting relatively stable conditions in the last 6000 years.

The global sea levels of the last 150,000 years can be reconstructed from foraminiferal oxygen isotope values (Martinson et al. 1987; Fig. 2.2). The reconstructed sea level shows that Aru has been a hilly promontory for about $80 \%$ of that time, becoming an island only during interglacial periods. Recent work (Chivas et al. 2000) on the Torresian plain has demonstrated the presence of numerous hardened layers of calcrete and ferricrete (limestone and iron concretions) within the upper Quaternary marine sediments. These represent the subaerial surfaces at times of the lowered sea level, when the sediments were welded by soil forming processes under semi arid conditions.

\section{Non-anthropogenic Quaternary deposits}

Sites for pollen analysis were sought in Aru by the present research team, but the karstic ponds encountered drained internally and were not suitable sites for long term sedimentation, being filled by red mud or having little sediment. Small lakes are shown on the map in the interior of Kobroor but could not be reached. Pollen was not preserved in the middens nor in other cave-fill sequences at Liang Nabulei Lisa or Liang Lemdubu. However, mid-Holocene sequences based on estuarine sediments are plentiful, consisting of peaty clays, sands, and mangrove muds. An infilled embayment on the west coast of Wamar Island was cored to see if a Holocene section was present, that could provide an environmental history to match to the archaeological sequence found in the Wangil midden (Chapter 6, this volume). The Wangil Core site (Lat: $5^{\circ} 47^{\prime} \mathrm{S}$, Long: $134^{\circ} 08^{\prime} \mathrm{E}$; Fig. 2.3 ) is in a small valley infilled by clays from surrounding slopes about $0.9 \mathrm{~m}$ above modern high water (assessed by levelling to the beach HWM). The site is in open woodland of Pandanus over sedge-grassland at present, but $100 \mathrm{~m}$ down the valley is an area of dense sago swamp, and beyond that mangroves are situated behind a low coastal sand barrier and flooded by a small estuarine stream. To the west and north of the core site is a steep low ridge of mudstone on which Wangil midden is found. The footslopes of the ridge are currently gardened.

\section{Stratigraphy and dating}

The valley plain about $25 \mathrm{~m}$ south of the base of the ridge was augered with a bucket auger through silty clay to about $85 \mathrm{~cm}$. Below this, organic rich clays and silts were soft enough to be cored by D section auger to $250 \mathrm{~cm}$, where gravelly sand or rock was encountered (Table 2.2). Samples were collected at $10 \mathrm{~cm}$ intervals for pollen analysis, and organic materials from $60 \mathrm{~cm}$ and $240 \mathrm{~cm}$ for dating.

Estuarine infill commenced as the rising sea level flooded the shallow valley about $7750 \mathrm{cal}$ $\mathrm{BP}$. The dates on organic matter show that the bulk of the section infilled rapidly with estuarine muds at a rate of ca. $20 \mathrm{~cm} / 100 \mathrm{yr}$, but since around $6850 \mathrm{cal}$ BP sediment has accumulated at only $1 \mathrm{~cm} / 100 y r$ under intermittently dry conditions. This abrupt slowing of sedimentation mirrors the well-dated sections from macro-tidal northern Australia, where onshore sediment transport brought the estuary to an equilibrium with high tide levels within a few millennia of the flooding event (Woodroffe et al. 1985).

\section{Pollen analysis and vegetation history}

Pollen samples were taken at $10 \mathrm{~cm}$ intervals down the core, and $2 \mathrm{ml}$ suspended and treated with dilute $\mathrm{HCl}$ to remove carbonates. The samples were washed on 8 micron mesh to remove clay, and then treated by standard acetolysis methods. Pollen was not abundant and the pollen diagram has been prepared with total counts of between 120 and 250 (Fig. 2.4). A CONISS analysis of the common pollen types divides the diagram into four zones, with the following inferred chronology as calibrated years BP at 2 sigma, assuming the two sedimentation rates were constant and allowing for stratigraphic imprecision in the zone boundary levels (Table 2.3). 


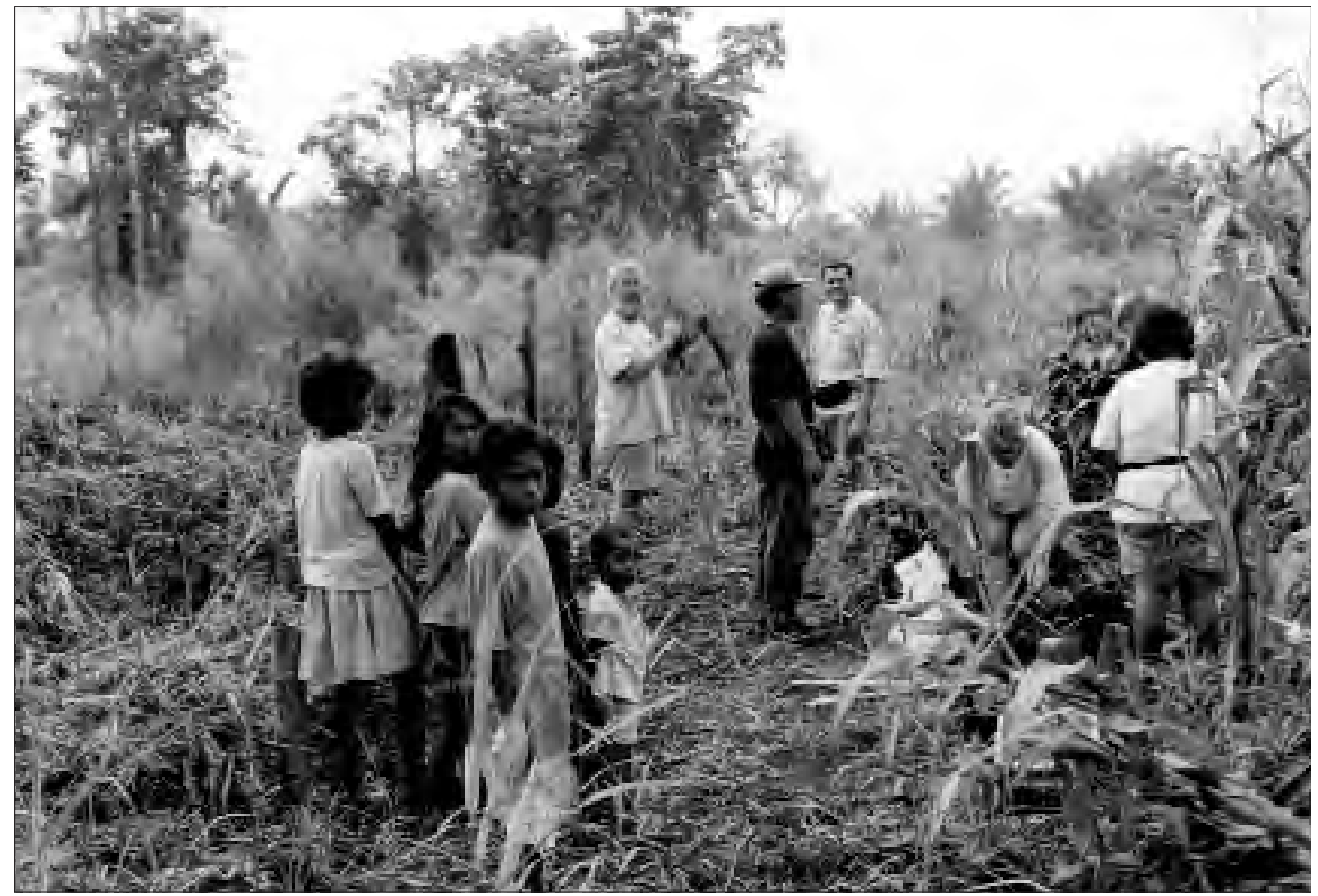

Figure 2.3 Wangil: The authors taking a core behind a beach ridge at Wangil, Dobu Island (altitude $1 \mathrm{~m}$ ). The site is a former mangrove swamp that has gradually filled up with mud until a seasonally flooded forest invaded. At $58 \mathrm{~cm}$ mangroves give way to disturbed forest. The large Wangil midden site (see Chapter 6, this volume) occurs on the adjacent ridge. Photo Sue $0^{\prime}$ Connor

Zone WGL 4. This zone contains moderate levels of Rhizophoraceae which confirms that the lower sediments are estuarine. Except for an unknown tricolporate, possibly another mangrove, or gallery forest trees, the other components are sparse or intermittent. Neonauclea, a tropical savannah tree, has a peak but is likely to be a component of forest as grass, and surprisingly Casuarina, are absent. The site may have been an open quiet estuary at this time, with a fringing band of mangroves that filtered out dryland pollen. A succession is apparent as Rhizophora pollen increases towards the top of the zone, and occasional grains of Barringtonia and sago palm may reflect a swamp forest inland of the mangroves. Charcoal is at very low levels.

Zone WGL 3. Mangrove pollen increases to a maximum in this zone, which may reflect the development of a closed mangrove
Table 2.2 Wangil Core: stratigraphy and dating

\begin{tabular}{|c|c|}
\hline DEPTH (CM) & SEDIMENT \\
\hline $0-5$ & Fibrous peat with roots \\
\hline $5-29$ & Black organic-rich clay \\
\hline $29-52$ & $\begin{array}{l}\text { Brown clay with an orange mottle and root cracks filled with } \\
\text { fine sand and black silts }\end{array}$ \\
\hline $52-59$ & White silts with scattered orange nodules \\
\hline $59-88$ & $\begin{array}{l}\text { Mottled yellow-brown silty clay with scattered organic lenses. } \\
\text { Organic material at } 60 \mathrm{~cm} \text { gave } \\
\text { an AMS age of } 6030 \pm 40 \mathrm{BP}(0 \mathrm{~S}-35221)\end{array}$ \\
\hline $88-240$ & $\begin{array}{l}\text { Grey fine sandy silts with wood and gastropod shells below } \\
100 \mathrm{~cm} \text {. Wood fragments at } 240 \mathrm{~cm} \text { gave } \\
\text { an AMS age of } 6890 \pm 60 \mathrm{BP}(0 \mathrm{~S}-35318)\end{array}$ \\
\hline $240->255$ & Coarse sandy gravel with coral fragments \\
\hline
\end{tabular}

Table 2.3 Wangil Core: zones and inferred chronology (cal BP, 2 sigma) from CONISS analysis

\begin{tabular}{lccc}
\hline ZONE & INTERVAL (CM) & TOP & BASE \\
\hline WGL 1 & $0-15$ & Modern & $2075-1350$ \\
WGL 2 & $15-58$ & $2075-1350$ & $6950-6750$ \\
WGL 3 & $58-130$ & $6950-6750$ & $7325-7100$ \\
WGL 4 & $130-240$ & $7325-7100$ & $7800-7725$ \\
\hline
\end{tabular}




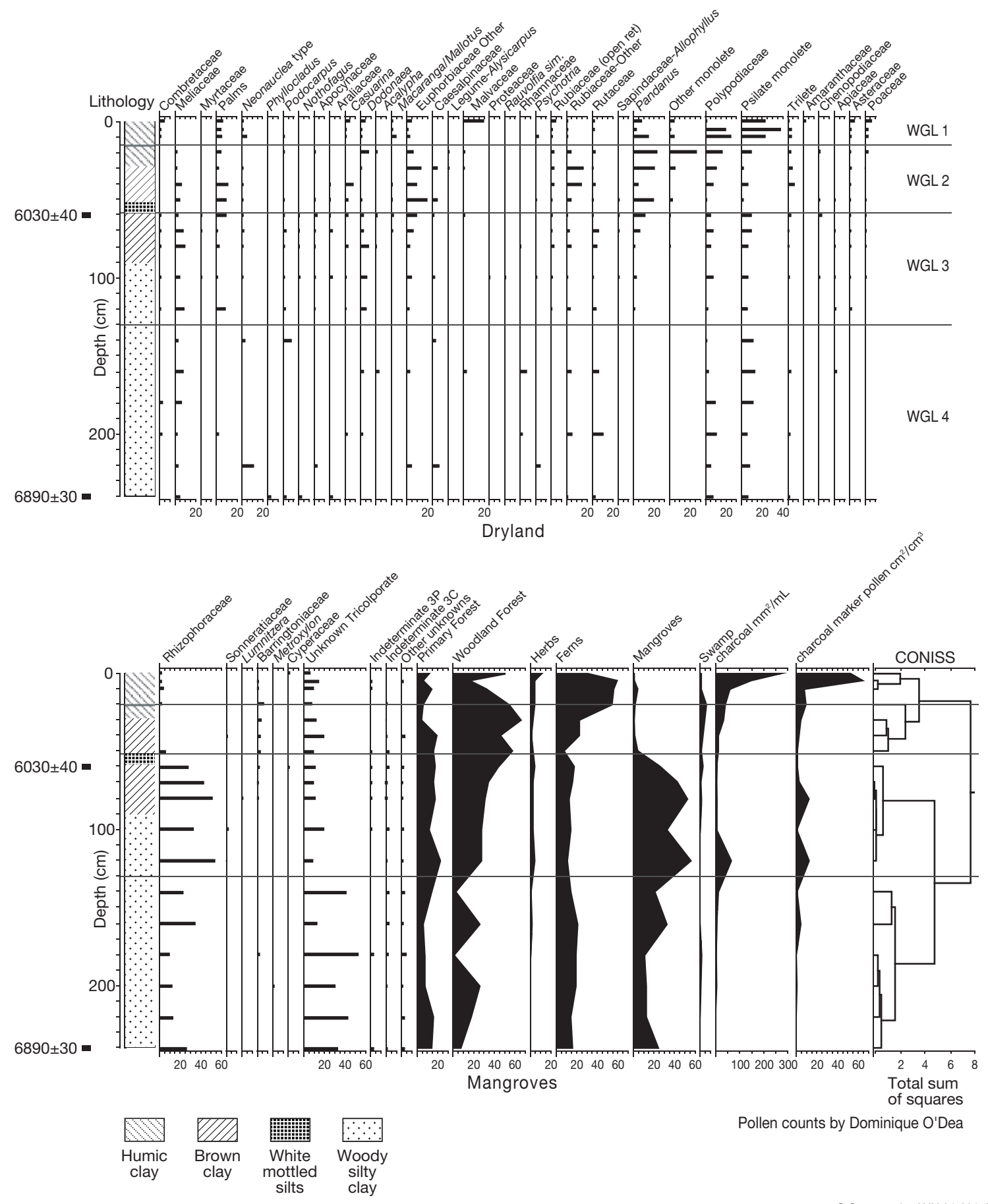

๑) Cartography ANU 04-021_2.4

Figure 2.4 Wangil: pollen diagram from core. Pollen sum is total pollen and spores

forest on site as water depth became less. A decline commences at $70 \mathrm{~cm}$, near the top of the zone. The unknown tricolporate grains decrease but remain a significant component to the top of the diagram, suggesting that they have a dryland source. Their decrease coincides with an increase in tree and shrub pollen so that the input from a mixed forest including the unknown may have remained steady, but diversity increased. Charcoal has a peak at the base of the zone but is not important above that. However, some disturbance is indicated by an increase in secondary taxa 
such as Dodonaea, Casuarina, Macaranga, and other Euphorbiaceae. More open conditions are indicated by the first traces of grass and Asteraceae pollen, and an increase in Pandanus.

Zone WGL 2. The rapid decline in mangrove pollen to very low levels is achieved at the start of this zone, and subsequent Rhizophoraceae may be the result of the re-working of older sediments. This change is a succession to dry land, borne out by the stratigraphy and the consistent presence of Barringtonia, which prefers wet non-saline sites. The pollen of Pandanus palms and disturbance taxa such as Casuarina, Dodonea, and Euphorbiaceae, reach their maximum in this zone, but Meliaceae and Rubiaceae (possibly representing less disturbed forest) decline above $40 \mathrm{~cm}$. Weed indicators such as some ferns, grass and daisies become more common in the upper $40 \mathrm{~cm}$. This change correlates with a distinct increase in charcoal, so that increased disturbance by fire and clearing seem likely at an inferred age of 4400-3600 cal BP.

Zone WGL 1. This zone is probably less than 1000 years old and may even represent the changing land use of colonial times. Since the surface organic sediments typically accumulate more quickly, the long term average used to infer the age of the Zone 2-1 boundary is a maximum. The zone is typified by considerable increases in ferns and a wide range of shrubs and herbs including some plants associated with gardening, such as possible Terminalia, palms, Pandanus, grass and Asteraceae. A single peak of Malvaceae (possibly Hibiscus) and Chenopodiaceae occurs only in the top $5 \mathrm{~cm}$. However, some secondary trees such as Euphorbiaceae are reduced, implying more extensive clearance. Charcoal reaches its highest levels. This zone thus reflects modern levels of disturbance and utilization of the catchment, with very common burning off.

This mid-Holocene sequence reflects a normal process of rapid infill of the heads of embayments, by species that are widespread to the present. The presence of some anthropogenic disturbance throughout seems likely but forest decline and clearance becomes more obvious around 4000-3000 years ago. Similar sequences might be expected around the coast of the archipelago, although the rate of estuarine infill and possibly the degree of disturbance could vary considerably.

\section{Environmental implications of vertebrate faunal change}

The two cave sites of Liang Nabulei Lisa and Liang Lemdubu together provide a more or less continuous record of vertebrate faunal change from around 28,000 years ago to the present (see Chapters 7 and 9, this volume, for details of site location and dating). The major changes can be summarized as follows:

Phase I (ca. 28,000-ca. 20,000 cal BP)

This period is recorded in Lemdubu Spits 31-19. The vertebrate fauna from this period makes it is clear that the dominant vegetation community in the vicinity of the site was relatively dry and open, probably savannah woodland with grassy understorey. This supported a range of species, today found in savannah woodland and grasslands of the Trans-Fly and across northern Australia. However, the presence in the same levels of many species found today in rainforest or dense gallery forest also points to the presence in the area of substantial patches of wetter, denser vegetation. These communities presumably occupied topographic lows in the karst landscape, including the major drainage features.

Exactly how much of the area was occupied by each of these vegetation communities is difficult to judge. However, the fact that the two largest of the obligate rainforest animals are recorded only sporadically through this period suggests either that the wetter forest communities were of insufficient size and continuity to support viable populations of larger animals, or that these patches were subject to early and intense hunting pressure such that the larger animals were rapidly extirpated. If the latter process took place, then it left no archaeological signature. 
Phase II (ca. 20,000-ca. 12,000 cal BP)

The earlier part of this period is recorded in Lemdubu, and in both sites from 16,000 cal BP onwards. In Lemdubu, this phase is characterized by an increase in the relative abundance of the dry community taxa and a corresponding fall in those taxa associated with wetter, denser habitats. Although the transition point between this phase and the last is set at the boundary between Spits 18 and 19, the transition between the two phases is really a gradual one, with different taxa most likely responding to common stimuli at different times and rates. However, the overall impression is that rainforest patches probably declined in both extent and quality through this period. This may have occurred as a result of climatic deterioration or through increasing pressure on these habitats as a consequence of hunting and/or general exploitation of forest products. The timing of this change, which corresponds with the peak of the last glaciation, perhaps lends weight in favour of a climatic explanation.

Occupation of Nabulei Lisa probably commenced around 16,000 cal BP. The fauna from this period (Spits 43-33) points to the presence of substantial areas of open habitat in the vicinity of the site, but with sufficient areas of rainforest to support large mammals such as a Dorcopsis wallaby. The most likely scenario is that patches of dense evergreen or semi-evergreen rainforest were present near Nabulei Lisa, most likely in sheltered contexts along watercourses including the major sungai channels. Drier, more open habitats presumably dominated on more elevated and exposed sites away from the channels; these drier habitats are recorded in the Lemdubu fauna from this period.

Nabulei Lisa provides little evidence of the exploitation of freshwater resources such as crabs and economically useful molluscs during this period. This raises the possibility that the major sungai were seasonally dry, to the extent that these aquatic organisms were unable to establish viable, long-term populations. The apparent absence of cassowaries in the local area during the earlier part of this period (below Spit 35 in Nabulei Lisa) might also be taken as an indicator that conditions were drier in comparison with subsequent periods.

Phase III (ca. 12,000-10,200 cal BP)

This phase is recorded in Nabulei Lisa Spits 32-26. At Lemdubu, this phase through to the recent phase is represented by a compressed sequence at the top of the site. The vertebrate fauna from this period in Nabulei Lisa documents a continuation of open savannah habitats in the area around the site. However, other changes in the fauna suggest a possible expansion of rainforest habitats, perhaps indicating some climatic amelioration. In addition, evidence of the more regular exploitation of aquatic resources suggests that the sungai may have supported larger bodies of permanent water at this time. At the same time, small quantities of typical estuarine and marine organisms were making their way to the site, marking the progressive inundation of the continental shelf.

\section{Phase IV (ca. 7700-6100 cal BP)}

This phase is recorded in Nabulei Lisa Spits 25-10. It is characterized mainly by the loss of the savannah and grassland-dwelling mammals - a clear signal that open habitats have either disappeared entirely or else become reduced to small remnants of insufficient size to support viable populations. In general terms, the local environment may have resembled that found around the site today but with a slightly more diverse mammal fauna. The brief appearance of freshwater turtle in the lower part of this period is further evidence that the major sungai supported at least a seasonally productive stream or wetland habitat. However, such conditions were evidently short-lived, and the dramatic increase in marine and estuarine shell above Spit 20, and simultaneous change in the crab fauna, clearly reflect the local establishment of estuarine conditions with associated mangrove communities in the sungai at that time. The crab fauna also suggests that marine conditions were established in the sungai from Spit 15 onwards. 


\section{Phase V (ca. 1000 cal BP-modern)}

This phase is recorded in Nabulei Lisa Spits 9-1. It is also recorded in the upper four spits in Lemdubu. The major faunal changes include the appearance of several introduced mammals (pig, dog and deer), an increase in the exploitation of fish, and a relative decline in the exploitation of terrestrial mammals and reptiles. Bats show a slight increase in relative abundance during this period. Cassowary bone and eggshell reappear during this period. The terrestrial mammals found in these levels are the same as those found on the islands today and are typical of closed rainforest habitats.

Unfortunately, the archaeological remains are too sparse to build a detailed picture of environmental changes during this interesting, final phase of occupation. Accordingly, it is unclear whether the sites were being used as remote hunting camps subject to occasional visits, or alternatively, whether the area around the sites was subject to cultivation.

\section{Discussion}

Aru is a remarkable outpost of the northern Arafura shelf, which provides a rare record of the changing terrestrial environments of the shelf as sea extent varied. From the point of view of origins, it has to be regarded as a continental island to New Guinea as it has direct connections to southern Papua for over $80 \%$ of the last million years, and its northerly position means that it has shared a warm tropical environment of less seasonality than northern Australia. The faunal changes found at Liang Lemdubu on Kobroor Island are the only direct evidence for climate fluctuations that have yet been found (see Chapters 7 and 9, this volume), but these results can be supplemented by regional studies of more detailed and longer term data.

\section{Regional climate change}

Several lines of evidence suggest that during glacial periods, conditions in Torresia - the biogeographic province between northern Australia and southern New Guinea - were much drier and slightly cooler than present (Walker 1972). The soils preserved on the Arafura plain to the south and east are indicative of dry and possibly seasonal conditions (Chivas et al. 2001). This is supported by evidence of the vegetation around Lake Carpentaria - a large, partly saline lake that formed on the eastern side of the plain (Torgersen et al. 1988; Chivas et al. 2001). Conditions were mostly treeless and the pollen of Chenopodiaceae, probably from desert steppe shrublands of saltbush, is common. It is assumed that the rainfall gradient between New Guinea and northern Australia was shifted northward (van der Kaars 1991), but in fact there are few precise records of this change. Patches of isolated eucalypt savannah occur north of Port Moresby and Merauke and may represent former northward retreat of the savannah-rainforest boundary. The long terrestrial record from the Atherton Tablelands of Queensland (Kershaw 1994; Kershaw et al. 2002) records cooler montane rainforest until about 35,000 years ago, when eucalypt woodlands start to increase. Lowland rainforest recovers the site about 8000 years ago. Kershaw considers that rainfall may have fallen to $35 \%$ of its modern total, but this represents an eastwards shift in the savannahrainforest boundary of only a few kilometres, as there is a steep rainfall gradient in the area.

Other long records in the region come from marine cores. Van der Kaars (1991) studied pollen and charcoal in cores from the Banda Sea and north of Australia and obtained vegetation records extending back to before the last glacial maximum (LGM). The most complete record is from the Lombok Rise and it was subsequently analysed further (Wang et al. 1999). At the same latitude $\left(5^{\circ} 46^{\prime} \mathrm{S}\right)$ as Aru, but $680 \mathrm{~km}$ to the west, van der Kaars et al. (2000) obtained a 175,000 year record. These records have been reviewed by Kershaw et al. (2002), and long climatic change indices have been calculated. Both spectra have high levels of fern spores and mangrove pollen 
during interglacial stages. During glacials, the spectra are dominated by grass with increases in Eucalyptus. This indicates that pollen was being derived by the southeast Trade winds from the Australian continental mass. Pollen from New Guinea is a minor component only, and lowland forest signals are low as well. Kershaw et al. (2002) suggest that this is due to cooler conditions which restricted the warm rainforests. This is supported by increased lower montane rainforest pollen from Lithocarpus and other lower montane trees. Upper montane taxa, such as Nothofagus and Phyllocladus are rare but increase markedly during the shift from glacial to interglacial, which Kershaw et al. (2002) suggest may be evidence for an increase in area of the upper montane zone in the Holocene. This is supported by pollen cores from northern New Guinea (Hope 1996). The data are interpreted as indicating temperatures $4-6^{\circ} \mathrm{C}$ cooler than present at the last glacial maximum. This estimate agrees with that of Hope (2001) from a site in Sulawesi, but contrasts with an analysis of oxygen isotopes from foraminifera from the northern Banda sea off Halmahera. Here, Barmawidjaja et al. (1993) found little shift in sea temperature, even though the pollen signature showed a lowering of the lower montane boundary.

Kershaw (1994) infers rainfalls of only 30\% of modern at the time of the lowest sea level on the Atherton Plateau, but his sites lie on very steep rainfall gradients. Van der Kaars (1991) suggests that rainfall boundaries were displaced about $200 \mathrm{~km}$ northwards across Torres Strait, implying that rainfall would have resembled that in the Darwin area today. However, since Aru lies outside cyclone tracks, the change would not be as extreme and summer rainfall was probably more reliable than Darwin, despite a longer dry season.

The major change associated with the end of the LGM was a rapid rise in sea level about 16,500 BP, followed by a rapid rise in temperature around 14,000 BP (van der Kaars et al. 2000). This date accords well with the appearance of obligate rainforest mammals at Liang Lemdubu, and so it is probably associated with increasing moisture as a warm shallow sea approached from the south. Change continues until ca. 9500 BP with fluctuations in rainforests across the HolocenePleistocene boundary in New Guinea. It is likely that rainfall steadily increased as Torres Strait flooded, with modern temperatures and rainfall being established in the early Holocene, about 9000 years ago. This is borne out by the loss of savannah fauna at Liang Lemdubu (Chapter 7), which must reflect the southwards movement of the boundary of closed forest. In north Queensland, Kershaw (1994) found that closed forest was more extensive between 7500 and ca. $4000 \mathrm{BP}$ than at present. This mid-Holocene extension possibly also occurred on Aru, and may possibly have been the result of more reliable climates rather than higher temperatures and rainfall (Hope et al. 2004).

In the Pleistocene, Aru would have been a notable feature on the otherwise monotonous open savannah of the Arafura plain. Even though rainforest was restricted, it probably occurred along the gorges of the sungai as these would have been spring fed and a source of permanent water during the dry season. The greater landscape variety and biotic diversity of these low hills must have been attractive to humans venturing inland from the coast. As the sea spread rapidly across the plain, the embayments cut off the peninsular from the west, south and north, and rainforests spread out from more restricted sites. The length of coastline rapidly increased, and maritime peoples would have been gradually concentrated along the Aru ridge. Within a single lifetime, coastal retreat of $20-50 \mathrm{~km}$ would have been apparent when the sea was around $30-50 \mathrm{~m}$ below present. Once sea level had stabilized, coastal habitats continued to adjust with the rapid development of sand spits, reefs and mangroves between ca. 7000 and 5000 years ago. 


\section{References}

van Balgooy, M.M.J. 1996. Vegetation sketch of the Aru Islands. In H.P. Nooteboom (ed.), The Aru Archipelago: Plants, Animals, People and Conservation, pp. 1-14. Amsterdam: Nederlandse Commissie Voor Internationale Natuurbescherming. Mededelingan 30.

van Balgooy, M.M.J. and H.P. Nooteboom. 1995. Report on the Botany of the Aru Islands. Leiden: Rijksherbarium. 12pp.

Barmawidjaja, B.M., E.J. Rohling, W.A. van der Kaars, C. Vergnaud Grazzini, and W.J. Zachariasse. 1993. Glacial conditions in the northern Molluca Sea region (Indonesia). Palaeogeography, Palaeoclimatology, Palaeoecology 101:147-67.

British Admiralty. 1998. Admiralty Tide Tables Vol. III Pacific Ocean and Adjacent Seas (including Tidal Stream Tables). British Admiralty Bureau.

Chappell, J.M.A., A. Omura, T. Esat, M. McCulloch, J. Pandolfi, Y. Ota, and B. Pillans. 1996. Reconciliation of late Quaternary sea levels derived from coral terraces at Huon peninsula with deep sea oxygen isotope records. Earth and Planetary Science Letters 141:227-36.

Chivas, A.R., A. García, S. van der Kaars, M. Couapel, J.J.S. Holt, J.M. Reeves, D.J. Wheeler, A.D. Switzer, C.V. Murray-Wallace, D. Banerjee, D.M. Price, S.X. Wang, G. Pearson, N.T. Edgar, L. Beaufort, P. De Deckker, E. Lawson, and C.B. Cecil. 2000. Sea-level and environmental changes since the last interglacial in the Gulf of Carpentaria, Australia: an overview. Quaternary International 83-85:19-46.

Flannery, T. 1995. Mammals of the South-West Pacific and Moluccan Islands. Sydney: Australian Museum/Reed Books. Gregory, J.W., L.R. Cox, and E.D. Currie. 1924. The geology of the Aru islands. Geological Magazine 61:52-72.

Gylstra, M.L.D. 1996. The use of remote sensing and GIS for classification of mangrove ecosystems on Aru. In H.P. Nooteboom (ed.), The Aru Archipelago: Plants, Animals, People and Conservation, pp. 15-34. Amsterdam: Nederlandse Commissie Voor Internationale Natuurbescherming. Mededelingan 30.

Hidayat, H. 2000. Forest Management by the Local Peoples in Aru District, Southeast Maluku. Unpublished Manuscript, LIPI 154-63. URL: http://iges.or.jp/en/fc/phase1.

Hope G.S. 2001. Environmental change in the Late Pleistocene and later Holocene at Wanda Site, Soroako, South Sulawesi, Indonesia. Journal of Palaeogeography, Palaeoclimatology, Palaeoecology 17:129-45.

Hope, G.S. 1996. Quaternary change and historical biogeography of Pacific Islands. In A. Keast and S.E. Miller (eds), The Origin and Evolution of Pacific Island Biotas, New Guinea to Eastern Polynesia: Patterns and Process, pp. 165-90. Amsterdam: SPB Publishing.

Hope, G.S., X. Sun, P-M. Liew, A.P. Kershaw, W.A. van der Kaars, H. Takahara, M. McGlone, L.E. Heusser, and N. Miyoshi. 2004. History of vegetation and habitat change from the PEP II transect. Quaternary International 118-119:103-26.

van der Kaars, W.A. 1991. Palynology of eastern Indonesian marine piston-cores: a late Quaternary vegetational and climatic record for Australasia. Palaeogeography, Palaeoclimatology, Palaeoecology 85:239-302.

van der Kaars, W.A. 1997. Marine and terrestrial pollen records of the last glacial cycle from the Indonesian region: Bandung Basin and Banda Sea. Palaeoclimates: Data and Modelling 4:1-11.

van der Kaars, W.A., X. Wang, P. Kershaw, F. Guichard, and D.A. Setiabudi. 2000. A late Quaternary palaeoecological record from the Banda Sea, Indonesia: patterns of vegetation, climate and biomass burning in Indonesia and northern Australia. Palaeogeography, Palaeoclimatology, Palaeoecology 155:135-53.

Kershaw, A.P. 1994. Pleistocene vegetation of the humid tropics of northeastern Queensland, Australia. Palaeogeography, Palaeoclimatology, Palaeoecology 109:399-412.

Kershaw, A.P., S. van der Kaars, P. Moss, and X. Wang. 2002. Quaternary records of vegetation, biomass burning, climate and possible human impact in the Indonesian-Northern Australian region. In A.P. Kershaw, B. David, N. Tapper, D. Penny, and J. Brown (eds), Bridging Wallace's Line: The Environmental and Cultural History and Dynamics of the Southeast Asian-Australian Region, pp. 97-118. Reiskirchen: Catena Verlag. Advances in GeoEcology 34.

Martinson, D.G., N.G. Pisias, J.D. Hays, J. Imbrie, T.C. Moore, and N.J. Shackleton. 1987. Age dating and orbital theory of the Ice Ages: development of a high resolution 0-300,000-year chronostratigraphy. Quaternary Research 27:1-29.

Monk, K.A., Y. De Fretes, and G. Reksodiharjo-Lilley. 1997. The Ecology of Nusa Tenggara and Maluku. Hong Kong \& Cambridge: Periplus and Cambridge University Press. Ecology of Indonesia Series 5.

Nooteboom, H.P. (ed.). 1996. The Aru Archipelago: Plants, Animals, People and Conservation. Amsterdam: Nederlandse Commissie Voor Internationale Natuurbescherming. Mededelingan 30.

Torgersen, T., J. Luly, P. De Deckker, M. Jones, D.E. Searle, A.L Chivas, and W.J. Ullman. 1988. Late Quaternary environments of the Carpentaria basin, Australia. Palaeogeography, Palaeoclimatology, Palaeoecology 67:245-61.

Verstappen, H.Th. 1959. Geomorphology and crustal movements of the Aru Islands in relation to the Pleistocene drainage of the Sahul shelf. American Journal of Science 257:491-502. 
Voris, H.K. 2000. Maps of Pleistocene sea levels in Southeast Asia: shorelines, river systems and time durations. Journal of Biogeography 27:1153-67.

Walker, D. (ed.). 1972. Bridge and Barrier: The Natural and Cultural History of Torres Strait. Canberra: Department of Biogeography and Geomorphology, Research School of Pacific Studies, The Australian National University.

Wallace, A.R. 1857. On the natural history of the Aru Islands. Annals and Magazine of Natural History (Series 2) 20:473-85.

Wallace, A.R. 1869. The Malay Archipelago: The Land of the Orang-utan and the Bird of Paradise. A Narrative of Travel with Studies of Man and Nature. London: MacMillan.

Wang, X., S. van der Kaars, A.P. Kershaw, M. Bird, and F. Jansen. 1999. A record of fire, vegetation and climate through the last 3 glacial cycles from Lombok Ridge core G6-4, eastern Indian Ocean, Indonesia. Palaeogeography, Palaeoclimatology, Palaeoecology 147:241-56.

Wollaston, A.F.R. 1912. Pygmies and Papuans. London: Smith Elder.

Woodroffe, C.D., J.M.A. Chappell, B.G. Thom, and E. Wallensky. 1985. Stratigraphy of the South Alligator tidal river and plains, Northern Territory. In K.S. Bardsley, J.D.S. Davie, and C.D. Woodroffe (eds), Coasts and Tidal Wetlands of the Australian Monsoon Region, pp. 17-42. Darwin: Australian National University North Australia Research Unit. Mangrove Monograph 1.

Yokoyama, Y., A. Purcell, K. Lambeck, and P. Johnston. 2001a. Shore-line reconstruction around Australia during the Last Glacial Maximum and Late Glacial Stage. Quaternary International 83-85:9-18.

Yokoyama, Y., P. De Deckker, K. Lambeck, P. Johnston, and L.K. Fifield. 2001b. Sea-level at the Last Glacial Maximum: evidence from northwestern Australia to constrain ice volumes for Oxygen isotope Stage 2. Palaeogeography, Palaeoclimatology, Palaeoecology 165:281-97. 